\title{
Pendekatan Saintifik Berbasis E-learning untuk Meningkatkan Kemampuan Berpikir Kreatif Matematis \& Self-confidence
}

\author{
Dahlia Fisher', R. Poppy Yaniawati², In in Supianti², Mira Mariani² \\ 1. Program Studi Pendidikan matematika, Fakultas Keguruan dan Ilmu \\ Pendidikan Universitas Pasundan, Jl. Tamansari No. 6-8 Bandung \\ 2. Magister Pendidikan Matematika Universitas Pasundan, Jl. Sumatera No. 6 \\ Bandung \\ pyaniawati@unpas.ac.id
}

Received: 24 Oktober 2019;Accepted: 6 November 2019; Published: 29 Desember 2019

\begin{abstract}
Abstrak
Pendekatan Saintifik berbasis e-learning dapatmeningkatkan Kemampuan Berpikir Kreatif Matematis dan Self-confidence Siswa. Kemampuan berpikir kreatif matematis dan self-confidence merupakan aspek penting yang perlu dikuasai siswa untuk meningkatkan hasil belajar matematika. Resources-Based Learning dengan pendekatan Scientific menggunakan media e-learning adalah sebuah metode pembelajaran inovatif yang memungkinkan siswa untuk dapat melaksanakan pembelajaran berbasis aneka sumber melalui kerangka ilmiah yang didukung dengan media interaktif berbasis teknologi informasi. Penelitian ini mengungkapkan pengaruh metode Resources-Based Learning dengan pendekatan Scientific menggunakan media e-learning terhadap peningkatan Kemampuan berpikir kreatif matematis dan self-confidence siswa. Subjek penelitian ini adalah siswa kelas VII Semester 2 dari 3 kelas yang sudah terbentuk.Teknik pengumpulan data dilakukan melalui tes dan angket yang dianalisis dengan statistik anova satu jalur. Berdasarkan hasil analisa data, diperoleh bahwa kemampuan berpikir kreatif matematis dan self-confidence siswa yang pembelajarannya melalui Resources-Based Learning dengan pendekatan Scientific menggunakan media e-learning lebih baik dibandingkan melalui Resources-Based Learning tanpa menggunakan media e-learning dan pembelajaran konvensional, dimana terdapat korelasi yang signifikan antara kemampuan berpikir kreatif matematis dengan self-confidence.
\end{abstract}

Kata kunci: Resources-Based Learning, Pendekatan Scientific, e-learning, kemampuan berpikir kreatif matematis, self-confidence

\begin{abstract}
Resources-Based Learning to Improve the Student's Creative Thinking Ability Mathematically and Selfconfidence. The ability of Creative Thinking Mathematically and self-confidence is an important aspect that students needed have to improve learning outcomes. Resources-Based Learning with Scientific approach using e-learning media is an innovative learning method that enables students to implement various resource-based learning through a Scientific framework supported by interactive media based on information technology. This research describes the influence of Resources-Based Learning with Scientific approach using e-learning media to improve the ability of Creative Thinking Mathematically and selfconfidence. The subject is the seventh class second semester from three classes that have been formed. Data collection techniques with tests and questionnaires were analyzed with one-way anova statistics. The results show that students who learned through Resources-Based Learning with Scientific approach using elearning media are much better in the ability than students who learned through Resources-Based Learning without e-learning and conventional. In addition, there is a significant correlation between the ability of Creative Thinking Mathematically and self-confidence.
\end{abstract}


Keywords: Resources-Based Learning, approach Scientific, e-learning, creative thinking ability mathematically, self-confidence 
Dahlia Fisher, R. Poppy Yaniawati

In in Supianti, Mira Mariani

\section{PENDAHULUAN}

Salah satu aspek keterampilan Standar Kompetensi Lulusan (SKL) siswa SMP menurut Permendikbud Nomor 20 Tahun 2016 (Kemendikbud, 2016) adalah memiliki keterampilan berpikir dan bertindak (1) kreatif, (2) produktif, (3) kritis, (4) mandiri, (5) kolaboratif, dan (6) komunikatif melalui pendekatan ilmiah sesuai dengan yang dipelajari di satuan pendidikan dan sumber lain secara mandiri. Pada konteks pembelajaran matematika, penguasaan keterampilan yang sesuai dengan SKL sangat diperlukan agar siswa mampu menyelesaikan permasalahan matematika, termasuk soal yang rumit dan tidak rutin.

Pembelajaran matematika banyak berkaitan dengan proses penyelesaian masalah yang tidak selalu bergantung kepada rumus baku. Permasalahan matematika yang sulit justeru menuntut adanya kemampuan berpikir kreatif yang bisa menghubungkan kemampuan dengan kreatifitas untuk menciptakan inovasi dalam menyelesaikan masalah dengan cara yang bervariasi.

Hal ini sesuai dengan Ruggiero (2012 : 7) yang menyatakan bahwa berpikir kreatif adalah cara berpikir yang menghasilkan beragam konsep permasalahan disertai berbagai cara untuk menghadapinya serta kemungkinan yang bisa menjadi solusi untuk menanggapinya. Dengan demikian, siswa yang memilliki kemampuan berpikir kreatif akan lebih berhasil dalam pembelajaran matematika karena mampu mengembangkan wawasan dan kemampuan yang dimilikinya untuk menciptakan berbagai kreativitas dalam mennyelesaikan suatu permasalahan.

Selain faktor kognitif, pembelajaran matematika juga membutuhkan faktor afektif yang perlu dikuasai yaitu self-confidence. McPheat (2010 : 14) menyatakan bahwa selfconfidence merupakan keyakinan yang dimiliki seseorang untuk bisa menyelesaikan suatu pekerjaan meskipun tidak pernah memiliki pengalaman dalam bidang tersebut. Selfconfidence merupakan sikap positip yang diperlukan untuk membangun keyakinan terhadap kemampuan yang dimilikinya.

Kloosterman (Nurqolbiah, 2016 : 226) menyatakan bahwa keberhasilan dan kegagalan yang dicapai siswa dipengaruhi oleh motivasi, kepercayaan diri, dan keyakinan akan usaha yang mereka lakukan. Galbraith and Haines (Foster, 2016 : 5) menyebutkan bahwa siswa yang percaya diri memiliki keyakinan bahwa mereka akan mendapatkan hasil dari sebuah usaha, tidak kuatir menghadapi materi pembelajaran yang sulit, selalu menginginkan hasil yang terbaik, dan menganggap matematika itu menyenangkan.

Salah satu metode pembelajaran yang dapat digunakan untuk membentuk aktivitas siswa sekaligus meningkatkan kemampuan berpikir kreatif matematis dan self-confidence adalah Resources-Based Learning (RBL). Campbell (Aliyah, 2014 : 14) menyatakan bahwa Resource-Based Learning adalah model pembelajaran yang secara aktif melibatkan peserta didik dengan aneka ragam sumber belajar, baik cetak maupun non-cetak. Keunggulan metode pembelajaran ini dapat diketahui berdasarkan pernyataan MacCrate dan Carnegie (Butler, 2012 : 10) bahwa Resources-Based Learning dapat meningkatkan kemampuan siswa dalam memecahkan masalah secara efektif.

Dalam Resources-Based Learning guru bukan merupakan sumber belajar satu-satunya. Siswa dapat belajar dalam kelas, laboratorium, perpustakaan, ruangan khusus belajar, atau bahkan di luar sekolah ketika siswa mempelajari lingkungan yang berhubungan dengan tugas atau masalah tertentu. Namun belajar berdasarkan sumber juga tidak berarti menghilangkan peranan guru dalam memberikan pengawasan terhadap proses pembelajaran siswa. Dalam hal ini, guru tetap terlibat dalam setiap langkah pembelajaran dimulai dari perencanaan, penentuan, pengumpulan informasi, pemberian motivasi, 
memperbaiki kesalahan dan memberi bantuan terhadap siswa.

Metode Resources-Based Learning dengan pendekatan Scientific merupakan pembelajaran berbasis aneka sumber yang menggunakan kerangka ilmiah yang meliputi kegiatan mengamati untuk mengidentifikasi hal-hal yang ingin diketahui, merumuskan pertanyaan dan merumuskan hipotesis, mengumpulkan data dengan berbagai teknik, mengasosiasi / menganalisis / mengolah data dan menarik kesimpulan serta mengkomunikasikan hasilnya untuk memperoleh pengetahuan, keterampilan dan sikap. Sejalan dengan kemajuan teknologi informasi yang telah dicapai, Resources-Based Learning dengan pendekatan Scientific juga dapat dikembangkan melalui penerapan $e$ learning.

Menurut Cute (Yaniawati, 2013 : 110), elearning adalah konten instruksional atau pengalaman pembelajaran yang dihasilkan atau sediakan melalui media elektronik. Melalui $e^{-}$ learning, proses pembelajaran dapat dilaksanakan secara interaktif dan lebih menarik agar mampu meningkatkan minat dan semangat siswa dalam belajar. Dengan demikian, model Resources-Based Learning dengan pendekatan Scientific menggunakan media e-learning merupakan sebuah metode pembelajaran inovatif yang memungkinkan siswa dapat melaksanakan pembelajaran berbasis aneka sumber yang menggunakan kerangka ilmiah dengan dukungan media interaktif berbasis teknologi informasi.

Sejalan dengan hal tersebut, peneliti terdorong untuk melakukan kajian tentang penerapan metode Resources-Based Learning dengan Pendekatan Scientific menggunakan media $e$ learning terhadap peningkatan kemampuan berpikir kreatif matematis dan self-confidence siswa. Tujuan dari kajian ini adalah (1) untuk mengetahui peningkatan kemampuan berpikir kreatif matematis dan self-confidence dari siswa yang mendapat perlakuan pembelajaran dengan metode Resources-Based Learning dengan Pendekatan Scientific tanpa media $e$ learning, metode Resources-Based Learning dengan Pendekatan Scientific menggunakan media e-learning, serta metode konvensional; (2) mengetahui korelasi antara kemampuan berpikir kreatif matematis dengan selfconfidence siswa.

\section{METODE}

Metode penelitian yang digunakan dalam penelitian ini adalah metode campuran (mixed methods) yang menggabungkan penelitian kualitatif dan kuantitatif, dimana data dikumpulkan dan dianalisis, mengintegrasikan temuan yang diperoleh dan menarik kesimpulan secara inferensial. Penelitian dilaksanakan dengan pendekatan eksperimental melalui dua perlakuan khusus pada kelompok yang berbeda dan kelompok kontrol. Kelompok eksperimen terdiri dari kelompok yang mendapat perlakuan ResourcesBased Learning dengan Pendekatan Scientific (X1) yang disebut kelompok eksperimen-1 dan kelompok yang mendapat perlakuan ResourcesBased Learning dengan Pendekatan Scientific menggunakan media e-learning (X2) yang disebut kelompok eksperimen-2, sedangkan Kelompok kontrol mendapat pembelajaran konvensional (Xo) yang disebut kelompok kontrol sebagaimana desain berikut.

$\begin{array}{lllll}\mathrm{A} & : & \mathrm{O} 1 & \mathrm{X} 0 & \mathrm{O} 2 \\ \mathrm{~A} & : & \mathrm{O} 1 & \mathrm{X} 1 & \mathrm{O} 2 \\ \mathrm{~A} & : & \mathrm{O} 1 & \mathrm{X} 2 & \mathrm{O} 2\end{array}$

Keterangan :

A : $\quad$ Kelas yang telah terbentuk sebelumnya

O1 : Pretes kemampuan berpikir kreatif matematis 
Dahlia Fisher, R. Poppy Yaniawati

In in Supianti, Mira Mariani

O2 : Postes kemampuan berpikir kreatif matematis

Xo : $\quad$ Metode konvensional

X1 : $\quad$ Metode Resources-Based

Learning dengan Pendekatan Scientific

X2 : $\quad$ Metode Resources-Based

Learning dengan Pendekatan Scientific

menggunakan media e-learning

Penelitian dilakukan di SMPN 9 Sumedang dengan subjek sebagai berikut : (1) kelas eksperimen 1 yang menerapkan model Resources-Based Learning dengan Pendekatan Scientific berjumlah 42 siswa; (2) kelas kelas eksperimen 2 yang menerapkan model Resources-Based Learning dengan Pendekatan Scientific menggunakan media e-learning berjumlah 40 siswa; dan (3) kelas kontrol yang menerapkan model konvensional berjumlah 42 siswa.

Uji hipotesis yang digunakan dalam penelitian ini adalah Uji Anova satu jalur. Pengujian dilaksanakan untuk mengetahui ada atau tidaknya perbedaan peningkatan kemampuan berpikir kreatif matematis dan self-confidence siswa yang menerapkan model ResourcesBased Learning dengan Pendekatan Scientific, model Resources-Based Learning dengan Pendekatan Scientific menggunakan media $e-$ learning dan model konvensional.
Kelompok yang lebih baik ditentukan berdasarkan nilai rata-rata statistik yang diperoleh pada setiap kelompok pembelajaran, yaitu rata-rata $\mathrm{n}$-Gain dari hasil tes kemampuan berpikir kreatif matematis dan rata-rata skor angket self-confidence berdasarkan skala Likert.

Instrumen yang dipergunakan dalam penelitian telah melalui uji instrumen masing-masing. Untuk soal kemampuan berpikir kreatif matematis, pengujian yang dilakukan adalah uji validitas instrumen, reliabilitas, tingkat kesukaran dan daya pembeda, sedangkan pada angket self-confidence dilakukan pengujian yang meliputi uji validitas dan reliabilitas instrumen. Media e-learning yang dipergunakan dalam penelitian ini adalah aplikasi yang dirancang khusus untuk materi pembelajaran segi empat dan aplikasi GeoGebra yang dipadukan dengan materi Powerpoint.

\section{HASIL DAN PEMBAHASAN}

Hasil pengolahan data statistik pretes kemampuan berpikir kreatif matematis dari setiap kelas menunjukan bahwa baik nilai ratarata hasil prestes maupun kemampuan fluency, flexibility, originality, dan elaboration siswa pada setiap kelompok pembelajaran masih rendah sebagaimana tabel berikut.

Tabel 1

Data Statistik Hasil Pretes Kemampuan Berpikir Kreatif Matematis

\begin{tabular}{lcccccccccc}
\hline \multirow{2}{*}{ Data Statistik } & \multicolumn{4}{c}{ Statistik } & \multicolumn{4}{c}{ Kemampuan Berpikir Kreatif } \\
\cline { 2 - 10 } & N & Avrg & SD & Min & Max & Fluen & Flexi & Org & Elab & Avrg \\
\hline RBL Scientific & 40 & 54,28 & 6,44 & 41,33 & 65,00 & 1,93 & 1,70 & 1,50 & 1,48 & $\mathbf{1 , 7 1}$ \\
\hline $\begin{array}{l}\text { RBL Scientifice- } \\
\text { learning }\end{array}$ & 42 & 56,64 & 6,45 & 45,67 & 68,00 & 2,01 & 1,74 & 1,64 & 1,55 & $\mathbf{1 , 7 9}$ \\
\hline Konvensional & 42 & 56,40 & 6,10 & 43,57 & 71,67 & 2,06 & 1,69 & 1,69 & 1,48 & $\mathbf{1 , 8 0}$ \\
\hline Total Average & & $\mathbf{5 5 , 7 7}$ & $\mathbf{6 , 3 3}$ & $\mathbf{4 3 , 5 2}$ & $\mathbf{6 8 , 2 2}$ & $\mathbf{2 , 0 0}$ & $\mathbf{1 , 7 1}$ & $\mathbf{1 , 6 1}$ & $\mathbf{1 , 5 0}$ & $\mathbf{1 , 7 7}$ \\
\hline
\end{tabular}


Berdasarkan tabel 1 diperoleh bahwa hasil pretes dengan urutan terbaik diperoleh kelas RBL dengan Pendekatan Scientific menggunakan media e-learning dengan nilai rata-rata sebesar 56,64, selanjutnya kelas konvensional sebesar 56,40 dan terakhir kelas RBL dengan Pendekatan Scientific sebesar 54,28. Dengan demikian, kemampuan awal siswa pada setiap kelas tidak jauh berbeda dan masih terbilang rendah sesuai dengan nilai standar deviasi yang hampir seragam. kreatif matematis pada kelas eksperimen maupun kelas kontrol.

Adapun hasil pengolahan data statistik postes kemampuan berpikir kreatif matematis dari setiap kelas dapat ditunjukkan pada tabel berikut.

Tabel 2

Data Statistik Hasil Postes Kemampuanpikir Kreatif Matematis

\begin{tabular}{lcccccccccc}
\hline \multirow{2}{*}{ Data Statistik } & \multicolumn{4}{c}{ Statistik } & \multicolumn{4}{c}{ Kemampuan Berpikir Kreatif } \\
\cline { 2 - 10 } & N & Avrg & SD & Min & Max & Fluen & Flexi & Org & Elab & Avrg \\
\hline RBL Scientific & 40 & 73,64 & 5,44 & 63,67 & 86,33 & 2,69 & 2,33 & 2,10 & 2,50 & $\mathbf{2 , 4 6}$ \\
\hline $\begin{array}{l}\text { RBL Scientifice- } \\
\text { learning }\end{array}$ & 42 & 77,55 & 5,26 & 66,00 & 92,67 & 2,65 & 2,60 & 2,29 & 2,86 & $\mathbf{2 , 6 1}$ \\
\hline Konvensional & 42 & 72,45 & 5,21 & 62,67 & 82,00 & 2,48 & 2,17 & 2,10 & 2,60 & $\mathbf{2 , 3 6}$ \\
\hline Total Average & & $\mathbf{7 4 , 5 5}$ & $\mathbf{5 , 3 0}$ & $\mathbf{6 4 , 1 1}$ & $\mathbf{8 7 , 0 0}$ & $\mathbf{2 , 6 1}$ & $\mathbf{2 , 3 7}$ & $\mathbf{2 , 1 6}$ & $\mathbf{2 , 6 5}$ & $\mathbf{2 , 4 8}$ \\
\hline
\end{tabular}

Dari aspek kemampuan berpikir kreatif, dapat diketahui bahwa secara keseluruhan kemampuan berpikir kreatif matematis siswa masih rendah dengan nilai rata-rata hanya 1,76 . Dari 4 aspek kemampuan berpikir kreatif matematis, hanya kemampuan fluency yang tergolong kriteria cukup dengan nilai rata-rata 2,o0. Dalam hal ini, kemampuan berpikir kreatif matematis siswa dari setiap kelompok pembelajaran tidak berbeda jauh dimana kelas konvensional mendapat nilai rata-rata sebesar 1,80 diikuti kelas RBL dengan Pendekatan Scientific menggunakan media e- Learning sebesar 1,79 dan paling rendah kelas RBL dengan Pendekatan Scientific sebesar 1,71.

Adapun pengujian hipotesa melalui uji Anova satu arah terhadap pretes kemampuan berpikir kreatif matematis memberikan nilai signifikansi sebesar 0,186>0.05 (Ho diterima) yang menunjukkan bahwa tidak terdapat perbedaan yang signifikan dari kemampuan berpikir
Berdasarkan tabel 2 dapat diketahui bahwa nilai rata-rata, nilai minimum dan maksimum dari hasil postes pada setiap kelas menunjukkan perbedaan yang cukup signifikan dimana hasil terbaik ditunjukkan kelas RBL Scientific media e-learning dengan nilai rata-rata sebesar 77,55, selanjutnya kelas RBL Scientific dengan nilai rata-rata sebesar 73,64, dan terakhir kelas konvensional sebesar 72,45. Hal ini menunjukkan bahwa hasil pembelajaran dari kelas eksperimen lebih baik dari kelas kontrol, dimana kelas yang menggunakan metode RBL dengan Pendekatan Scientific menggunakan media e-learning lebih baik dari kelas lainnya.

Dari aspek kemampuan berpikir kreatif, dapat diketahui bahwa secara keseluruhan kemampuan berpikir kreatif matematis siswa sudah mengalami peningkatan. Hal ini ditunjukkan dari peningkatan keempat aspek kemampuan berpikir kreatif matematis yang mencapai nilai rata-rata 2,48 dengan kriteria 
cukup. Dalam hal ini, peningkatan aspek kemampuan berpikir kreatif matematis terbaik diperoleh siswa pada kelas RBL dengan Pendekatan Scientific menggunakan media $e$ learning dengan nilai rata-rata sebesar 2,61 diikuti kelas RBL dengan Pendekatan Scientific sebesar 2,46 dan terakhir kelas kovensional yang hanya mendapat nilai rata-rata sebesar 2,36 .

Adapun pengujian hipotesa melalui uji Anova satu arah terhadap postes kemampuan berpikir kreatif matematis memberikan nilai signifikansi sebesar $0,000<0.05$ (Ho ditolak) yang menunjukkan bahwa terdapat perbedaan yang signifikan untuk kemampuan berpikir kreatif matematis dari hasil postes pada setiap kelas.

Untuk mengetahui efektifitas dari setiap model pembelajaran terhadap peningkatan kemampuan berpikir kreatif matematis, maka dilakukan perhitungan gain berdasarkan nilai postes dan pretes kemampuan berpikir kreatif matematis siswa pada setiap kelas. Hasil pengolahan data statistik dari peningkatan kemampuan berpikir kreatif matematis siswa pada setiap kelompok metode pembelajaran dapat ditunjukkan melalui tabel berikut. sebesar 20,90 dengan indeks gain 0,48, selanjutnya kelas RBL dengan Pendekatan Scientific yang memperoleh gain rata-rata sebesar 19,36 dengan indeks gain 0,42, dan terakhir kelas konvensional yang memperoleh gain rata-rata sebesar 16,06 dengan indeks gain o,37. Perbedaan ini sesuai dengan hasil uji Anova satu arah dimana nilai signifikansi sebesar 0,000 < 0.05 (Ho ditolak) menunjukkan adanya perbedaan yang signifikan terhadap peningkatan kemampuan berpikir kreatif matematis pada setiap kelas. Peningkatan statistik dari gain kemampuan berpikit kreatif matematis dapat ditunjukkan pada grafik berikut.

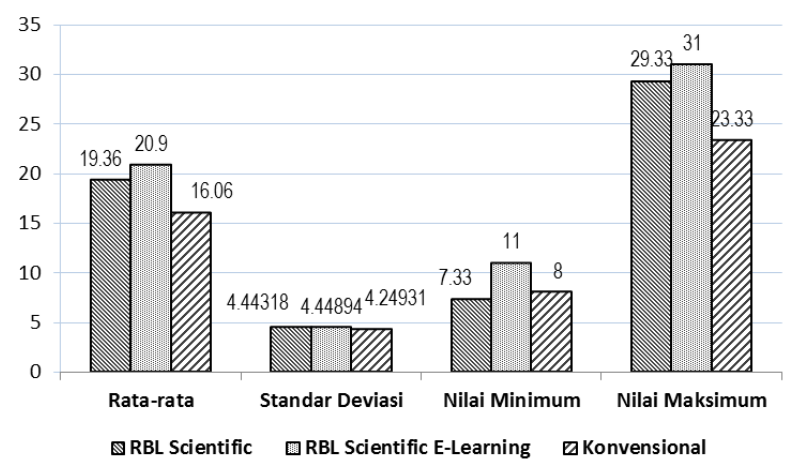

Gambar 1. Grafik Data Statistik Gain Kemampuan Berpikir Kreatif Matematis

Tabel 3

Data Statistik Gain Kemampuan Berpikir Kreatif Matematis

\begin{tabular}{lcccccccccc}
\hline \multirow{2}{*}{ Data Statistik } & \multicolumn{4}{c}{ Nilai Rata-rata } & \multicolumn{4}{c}{ Kemampuan Berpikir Kreatif } \\
\cline { 2 - 10 } & N & Pre & Pos & Gain & N-Gain & Fluen & Flexi & Org & Elab & Avrg \\
\hline RBL Scientific & 40 & 54,28 & 73,64 & 19,36 & 0.42 & 0,76 & 0,63 & 0,60 & 1,03 & $\mathbf{0 , 7 5}$ \\
\hline $\begin{array}{l}\text { RBL Scientifice- } \\
\text { learning }\end{array}$ & 42 & 56,64 & 77,55 & 20,90 & 0.48 & 0,64 & 0,86 & 0,64 & 1,31 & $\mathbf{0 , 8 2}$ \\
\hline Konvensional & 42 & 56,40 & 72,45 & 16,06 & $0 . .37$ & 0,42 & 0,48 & 0,40 & 1,12 & $\mathbf{0 , 5 7}$ \\
\hline Total Average & & $\mathbf{5 5 , 7 7}$ & $\mathbf{7 4 , 5 5}$ & $\mathbf{1 8 , 7 7}$ & $\mathbf{0 , 4 5}$ & $\mathbf{0 , 6 1}$ & $\mathbf{0 , 6 6}$ & $\mathbf{0 , 5 5}$ & $\mathbf{1 , 1 5}$ & $\mathbf{0 , 7 1}$ \\
\hline
\end{tabular}

Berdasarkan tabel 3 diperoleh bahwa hasil terbaik ditunjukkan pada kelas RBL dengan Pendekatan Scientific menggunakan media $e$ learning yang memperoleh gain rata-rata
Peningkatan pada aspek kemampuan berpikir kreatif matematis yang meliputi kemampuan fluency, flexibility, originality dan elaboration secara keseluruhan mencapai nilai rata-rata 
sebesar 0,71. Dengan kata lain, siswa mengalami peningkatan rata-rata hampir mencapai 1 level dari skala 4 pada penilaian

Kemampuan berpikir kreatif matematis. Dalam hal ini, peningkatan rata-rata kemampuan berpikir kreatif matematis tertinggi diperoleh kelas RBL dengan Pendekatan Scientific menggunakan media e-learning sebesar 0,82 diikuti kelas RBL dengan Pendekatan Scientific sebesar 0,75 dan paling rendah kelas konvensional sebesar 0,57 .

Untuk kemampuan fluency, hasil terbaik diperoleh kelas RBL dengan Pendekatan Scientific diikuti kelas RBL dengan Pendekatan Scientific menggunakan media e-learning dan paling rendah kelas konvensional. Sedangkan untuk kemampuan flexibility, originality dan elaboration, peningkatan tertinggi masingmasing diperoleh kelas RBL dengan Pendekatan Scientific menggunakan media e-learning diikuti kelas RBL dengan Pendekatan Scientific dan terakhir kelas konvensional.

Berdasarkan hasil tersebut, maka dapat disimpulkan bahwa peningkatan kemampuan berpikir kreatif matematis siswa pada kelompok RBL dengan Pendekatan Scientific menggunakan media e-learning lebih baik dari siswa pada kelas RBL dengan Pendekatan Scientific dan kelas konvensional yang mendapat peningkatan kemampuan berpikir kreatif matematis paling rendah.

Adapun hasil pengolahan data statistik hasil angket self-confidence siswa diukur dengan menggunakan skala Likert dimana nilai selfconfidence berkisar dari $1 \mathrm{~s} / \mathrm{d} 5$ sebagaimana ditunjukkan pada tabel berikut.
Tabel 4

\begin{tabular}{|c|c|c|c|}
\hline \multicolumn{4}{|c|}{$\begin{array}{c}\text { Data Statistik Hasil Angket Self-confidence } \\
\text { Kelas / Kelompok }\end{array}$} \\
\hline $\begin{array}{c}\text { Data } \\
\text { Statistik }\end{array}$ & $\begin{array}{c}\text { RBL } \\
\text { Scientifi } \\
c\end{array}$ & $\begin{array}{c}\text { RBL } \\
\text { Scientifice } \\
\text {-learning }\end{array}$ & $\begin{array}{c}\text { Konvensiona } \\
\text { l }\end{array}$ \\
\hline Rata-rata & 3,31 & 3,29 & 3,10 \\
\hline $\begin{array}{l}\text { Standar } \\
\text { Deviasi }\end{array}$ & 0,3610 & 0,3536 & 0,3900 \\
\hline $\begin{array}{l}\text { Nilai } \\
\text { Minimum }\end{array}$ & 2,73 & 2,57 & 2,20 \\
\hline $\begin{array}{l}\text { Nilai } \\
\text { Maksimu } \\
\mathrm{m}\end{array}$ & 4,20 & 3,93 & 4,07 \\
\hline $\begin{array}{l}\text { Jumlah } \\
\text { Nilai > } 3\end{array}$ & 29 & 32 & 28 \\
\hline $\begin{array}{l}\text { Jumlah } \\
\text { Objek }\end{array}$ & 40 & 42 & 42 \\
\hline
\end{tabular}

Berdasarkan tabel dimaksud dapat diketahui bahwa self-confidence siswa berada pada kondisi yang hampir sama di setiap kelas dimana nilai rata-rata self-confidence tertinggi diperoleh kelas RBL dengan Pendekatan Scientific sebesar 3,31 diikuti kelas RBL dengan Pendekatan Scientific menggunakan media $e$ learning sebesar 3,29 dan terakhir kelas konvensional sebesar 3,10. Dalam hal ini, jumlah siswa terbanyak yang memiliki nilai $>3$ terdapat pada kelas RBL dengan Pendekatan Scientific menggunakan media e-learning sebanyak 32 orang dari 42 siswa $(76,19 \%)$, diikuti kelas RBL dengan Pendekatan Scientific sebanyak 29 orang dari 40 siswa $(72,50 \%)$ dan terakhir kelas konvensional sebanyak 28 orang dari 42 siswa (66,67\%). Hal ini sesuai dengan hasil uji Anova satu arah terhadap selfconfidence memberikan nilai signifikansi sebesar $0,015<0.05$ (Ho ditolak) yang menunjukkan bahwa terdapat perbedaan yang signifikan untuk self-confidence dari hasil angket self-confidence pada setiap kelas.

Adapun hasil penilaian terhadap berbagai aspek self-confidence dari setiap kelas dapat digambarkan berdasarkan tabel berikut. 
Dahlia Fisher, R. Poppy Yaniawati

In in Supianti, Mira Mariani

Tabel 5

Hasil Penilaian terhadap berbagai aspek selfconfidence

\begin{tabular}{lccc}
\hline \multirow{1}{*}{ Aspek } & \multicolumn{3}{c}{ Rata-rata Nilai Kelas / Kelompok } \\
\cline { 2 - 4 } & $\begin{array}{c}\text { RBL } \\
\text { Scientific }\end{array}$ & $\begin{array}{c}\text { RBL } \\
\text { Scientifice- } \\
\text { learning }\end{array}$ & $\begin{array}{c}\text { Konven } \\
\text { sional }\end{array}$ \\
\hline $\begin{array}{l}\text { Menjaga citra } \\
\text { diriyangbaik }\end{array}$ & 3,16 & 3,02 & 2,87 \\
\hline $\begin{array}{l}\text { Berpikir } \\
\text { danbertindakp } \\
\text { ositif }\end{array}$ & 2,89 & 3,29 & 2,97 \\
\hline $\begin{array}{l}\text { Berbaur } \\
\text { dengan } \\
\text { oranglain }\end{array}$ & 3,62 & 3,46 & 3,21 \\
\hline $\begin{array}{l}\text { Bertindak } \\
\text { danberbicara } \\
\text { denganyakin }\end{array}$ & 3,22 & 3,13 & 3,24 \\
\hline $\begin{array}{l}\text { Membantu } \\
\text { oranglain } \\
\text { sepenuh hati } \\
\text { tanpa } \\
\text { mengharapkan } \\
\text { apapun }\end{array}$ & 3,14 & 3,27 & 2,82 \\
\hline $\begin{array}{l}\text { Aktif dan } \\
\text { antusias }\end{array}$ & 3,70 & 3,44 & 3,35 \\
\hline
\end{tabular}

Berdasarkan tabel dimaksud maka dapat diketahui bahwa aspek sikap yang meliputi berbaur dengan orang lain, bertindak dan berbicara dengan yakin, membantu orang lain sepenuh hati tanpa mengharap apapun serta aktif dan antusias rata-rata memiliki nilai $>3$ khususnya pada kelas RBL dengan Pendekatan Scientific dan RBL dengan Pendekatan Scientific menggunakan media e-learning. Dalam hal ini, kegiatan diskusi dan presentasi yang dilaksanakan pada pembelajaran telah memberikan dampak positip bagi terwujudnya pengembangan dari berbagai aspek sikap dimaksud.

Berdasarkan hasil yang diperoleh dari ketiga kelompok pembelajaran, maka dapat diketahui bahwa setiap metode pembelajaran mampu memberikan peningkatan terhadap kemampuan berpikir kreatif matematis dan self-confidence yang masing-masing berbeda secara signifikan. Sesuai dengan analisis data penelitian diperoleh bahwa peningkatan terbaik dari kemampuan berpikir kreatif matematis dan self-confidence terjadi pada kelompok RBL dengan Pendekatan Scientific menggunakan media e-learning, diikuti kelompok RBL dengan Pendekatan Scientific dan terakhir kelompok pembelajaran konvensional.

Pembelajaran matematika yang bersifat konvensional menjadi sebuah hambatan dalam mewujudkan kemandirian dan keaktifan siswa yang menjadi faktor pendukung dari peningkatan kemampuan berpikir kreatif matematis dan self-confidence. Kecenderungan guru matematika untuk mendominasi pembelajaran telah mengakibatkan rendahnya aktifitas siswa yang kurang diberi kesempatan untuk dapat terlibat langsung dalam kegiatan ilmiah. Kondisi tersebut berpengaruh pada terbatasnya peluang siswa untuk dapat berpikir secara kreatif atas pemikirannya sendiri dalam menemukan informasi atau gagasan baru dari proses pembelajaran. Keterbatasan itu tentunya perlu dihindari untuk mengoptimalkan kemampuan berpikir kreatif yang memerlukan ketekunan, disiplin pribadi dan perhatian yang melibatkan aktifitas mental seperti mengajukan pertanyaan, mempertimbangkan informasi baru dan gagasan yang tidak biasa dengan pikiran terbuka.

Pada sisi lain, kemampuan berpikir dan kreatifitas tidak akan dapat berkembang tanpa adanya sikap dan mentalitas positip yang mendukung terciptanya kebebasan berpikir dan berkreasi. Diperlukan sebuah kepercaya diri yang besar untuk bisa menyingkirkan rasa ragu yang menghambat terciptanya inovasi dan kreatifitas.. Dengan adanya kemampuan, keterampilan dan sikap percaya diri maka kesulitan dalam pembelajaran matematika akan bisa diselesaikan. Oleh karena itu, kemampuan berpikir kreatif matematis dan self-confidence menjadi aspek penting yang perlu terus 
ditingkatkan agar pembelajaran matematika dapat memberikan hasil yang lebih baik.

\section{Peningkatan Kemampuan Berpikir Kreatif Matematis}

Untuk mengetahui sejauh mana peningkatan kemampuan berpikir kreatif matematis yang didapatkan dari hasil pembelajaran, peneliti mempergunakan indikator yang mengacu pada pernyataan Munandar (Jazuli, 2009: 213) yaitu 1) fluency, 2) flexibility, 3) originality, dan 4) elaboration. Dengan demikian, pengukuran kemampuan berpikir kreatif matematis pada penelitian ini dititikberatkan pada penilaian aspek (1) fluency (kelancaran) yaitu kemampuan untuk mencetuskan banyak gagasan, jawaban, penyelesaian masalah atau pertanyaan; (2) flexibility (keluwesan) yaitu kemampuan menghasilkan gagasan, jawaban atau pertanyaan yang bervariasi, serta mengubah cara pendekatan dengan melihat masalah dari sudut pandang dan alternatif yang berbeda; (3) elaboration (keterperincian) yaitu kemampuan dalam mengembangkan suatu gagasan, menambah atau memperinci secara detil suatu obyek, gagasan, atau situasi yang dihadapi; dan (4) originality (keaslian) yaitu kemampuan untuk mengemukakan pendapat dirinya sendiri sebagai tanggapan terhadap suatu permasalahan yang dihadapi.

Peningkatan kemampuan berpikir kreatif matematis dapat diindikasikan dari tercapainya perkembangan kemampuan siswa pada saat sebelum dan sesudah penerapan metode pembelajaran. Berdasarkan hasil tes awal, maka dapat diketahui bahwa tidak terdapat perbedaan yang signifikan dari kemampuan berpikir kreatif matematis pada masing-masing kelompok pembelajaran. Dalam hal ini, kemampuan berpikir kreatif matematis ratarata masih rendah dimana siswa belum mampu mencetuskan banyak gagasan terhadap jawaban dan penyelesaian masalah yang dihasilkan dari pemikiran sendiri akibat kurang faham dan tidak mengerti situasi atau permasalahan yang dihadapi.
Hasil tes akhir dari setiap kelompok pembelajaran menunjukkan bahwa peningkatan kemampuan berpikir kreatif matematis pada setiap kelompok berbeda secara signifikan dimana hasil terbaik diperoleh pada kelompok RBL dengan Pendekatan Scientific menggunakan media e-learning dan kelompok RBL dengan Pendekatan Scientific. Artinya, kelompok RBL dengan Pendekatan Scientific lebih baik dari kelompok pembelajaran konvensional. Hal ini sejalan dengan hasil penelitian Khususwanto (2013) dan Ahmatika (2015) yang meyatakan bahwa peningkatan kemampuan berpikir kreatif matematis siswa yang menggunakan metode RBL dengan Pendekatan Scientific lebih baik dari pembelajaran konvensional.

Pada kelompok RBL dengan Pendekatan Scientific, siswa memiliki kesempatan untuk membangun pemahaman yang luas karena tidak dituntut untuk memperoleh informasi yang sama dengan siswa lainnya. Siswa justeru dituntut untuk dapat bersikap aktif dalam memperoleh informasi sebanyak-banyaknya agar bisa dipelajari secara bebas sesuai dengan batas kemampuan yang dimilikinya. Hal itu diharapkan mampu mendorong siswa agar dapat belajar dengan cara yang paling sesuai dengan bakat dan kemampuannya masingmasing.

Paradigma guru sebagai figur sentral di dalam kelas harus digeser menjadi sosok pembimbing yang mampu mengarahkan siswa agar dapat berperan secara aktif sebagai sosok sentral dalam pembelajaran. Guru bukan merupakan sumber belajar satu-satunya karena siswa dapat mencari atau memperoleh bahan pembelajaran dari berbagai sumber baik dari dalam maupun di luar kelas. Hal ini sesuai dengan definisi Resource Based Learning sebagai suatu proses pembelajaran yang langsung menghadapkan siswa dengan suatu atau sejumlah sumber belajar secara individual atau kelompok dengan segala kegiatan yang bertalian dengan sumber belajar, berbeda dengan pembelajaran matematika konvensional dimana guru menyampaikan bahan pelajaran kepada siswa 
yang jarang diberi kesempatan untuk mencari sumber lain sebagai referensi pendukung.

Berdasarkan hasil pengamatan peneliti ditemukan bahwa pendekatan Scientific dapat menumbuhkan keaktifan siswa dalam mengkonstruksi konsep, hukum atau prinsip melalui berbagai tahapan yaitu mengamati, mengidentifikasi dan merumuskan masalah, menyusun hipotesis, mengumpulkan data dengan berbagai teknik, menganlisis data, menarik kesimpulan dan mengkomunikasikan konsep, hukum atau prinsip yang ditemukan. Dengan demikian, siswa dapat memahami bahwa informasi bisa berasal dari mana saja dan kapan saja, tidak bergantung pada informasi searah dari guru. Hal ini sesuai dengan arahan Kemendikbud (2016) yang menyatakan bahwa kondisi pembelajaran perlu diarahkan untuk mendorong siswa agar dapat mencari tahu dari berbagai sumber melalui observasi dan bukan hanya diberi tahu.

Metode RBL dengan Pendekatan Scientific memfokuskan tujuan pada tercapainya kemampuan siswa dalam mengumpulkan, mengidentifikasi dan mengamati informasi, membuat hipotesis, menyusun pertanyaan dan mengolah informasi serta menarik kesimpulan dari penyelesaian masalah yang dapat dipecahkan. Dengan tercapainya tujuan dimaksud, siswa akan menguasai kemampuan berpikir kreatif matematis dari aspek kelancaran, keluwesan, ketelitian dan keorisinilan yang diperlukan untuk menyelesaikan berbagai permasalahan serta mempunyai kepekaan untuk menanggapi berbagai situasi dari sudut pandangnya sendiri.

Peningkatan kemampuan berpikir kreatif matematis dari hasil pembelajaran menunjukkan bahwa secara umum aspek fluency (kelancaran) telah mencapai kemajuan dimana siswa mulai mampu mencetuskan gagasan, jawaban, penyelesaian masalah atau pertanyaan dengan baik. Metode RBL dengan Pendekatan Scientific juga mampu meningkatkan aspek elaboration (keterperincian) karena siswa dituntut untuk dapat mengembangkan gagasan secara terperinci dalam proses pembelajaran. Kegiatan diskusi dan kerjasama yang dilaksanakan pada kelompok RBL dengan Pendekatan Scientific juga mampu memberikan dampak bagi peningkatan aspek originality (keaslian) yang diperlukan dalam mengemukakan pendapat dari sudut pandang pribadi.

Pada sisi lain, penggunaan media e-learning juga memberikan pengaruh positip terhadap peningkatan kemampuan berpikir kreatif matematis. Kemajuan teknologi yang terus berkembang telah membuka peluang bagi tercapainya ketersediaan sarana IT yang mampu mendukung peningkatan kemampuan matematis siswa. Hal ini sesuai dengan pendapat Yaniawati (2012) yang menyatakan bahwa pada masa globalisasi ini, untuk mengembangkan kemampuan matematis diperlukan suatu percepatan (acceleration) dalam proses pembelajaran matematika, karena pembaharuan informasi dapat memicu terwujudnya percepatan terhadap peningkatan wawasan siswa yang lebih luas.

Keunggulan dari segi teknologi informasi merupakan salah satu aspek penting yang diharapkan dapat mendukung tercapainya peningkatan kemampuan berpikir kreatif matematis siswa. Adanya media e-learning dengan beragam fitur yang dapat diterapkan pada proses pembelajaran akan memberikan dampak bagi peningkatan kemampuan flexibility (keluwesan) yang diperlukan dalam menyelesaikan masalah dari sudut pandang dan cara pendekatan yang berbeda.

Penerapan metode RBL dengan Pendekatan Scientific yang diintegrasikan dengan $e$ learning merupakan sebuah bentuk inovasi pembelajaran yang lebih baik dimana kemampuan edukatif guru dikombinasikan dengan keunggulan teknologi informasi. Menurut hasil penelitian Yaniawati (2012), kemampuan matematik siswa yang diperoleh melalui penerapan blended learning (kombinasi antara model e-learning dengan pembelajaran konvensional) lebih baik dari model full $e$ - 
learning dan konvensional. Sesuai dengan hal tersebut, metode RBL dengan Pendekatan Scientific menggunakan media e-learning dapat menjadi sebuah solusi bagi upaya pencapaian peningkatan kemampuan berpikir kreatif matematis karena memiliki keunggulan dari aspek teknologi dan metode pembelajaran yang berbasis aneka sumber, ilmiah, fleksibel dan berorientasi kepada siswa sebagai sosok sentral pembelajaran yang sesuai dengan kondisi dan kebutuhan aktual.

\section{Self-confidence}

Untuk mengetahui sejauh mana self-confidence dapat tumbuh dan berkembang dari hasil pembelajaran, peneliti mempergunakan indikator self-confidence yang meliputi (1) menjaga citra diri yang baik; (2) berpikir dan bertindak positif; (3) berbaur dengan orang lain; (4) bertindak dan berbicara dengan yakin; (5) membantu orang lain sepenuh hati tanpa mengharapkan apapun; (6) aktif dan antusias.

Terwujudnya sikap self-confidence dapat dilihat dari adanya sikap positip yang tumbuh dan berkembang selama proses pembelajaran. Berdasarkan hasil observasi terhadap responden, peneliti menemukan bahwa sikap self-confidence pada kelompok pembelajaran yang menggunakan metode RBL dengan Pendekatan Scientific relatif lebih baik dari kelompok pembelajaran konvensional. Hal ini sesuai dengan hasil penelitian Khususwanto (2013) dan Ahmatika (2015) yang menyatakan bahwa self-confidence siswa yang menggunakan metode Resources-Based Learning (RBL) dengan Pendekatan Scientific lebih baik dari siswa yang memperoleh pembelajaran konvensional. Indikator dari sikap self-confidence dapat dilihat dari sikap siswa yang bercirikan senang menghargai orang lain, dapat membangun sikap optimis, mampu bergaul dan bekerja sama dengan cukup baik, memiliki keberanian untuk bertindak dan berbicara, serta lebih bersikap aktif dalam proses pembelajaran.
Pelaksanaan diskusi dan presentasi yang berjalan kondusif dan penuh aktifitas merupakan salah satu kunci keberhasilan dalam membangun self-confidence siswa. Terjadinya interaksi dua arah antara guru yang berperan sebagai fasilitator dan koordinator dengan siswa yang memiliki kesempatan untuk menjadi sosok sentral dalam kegiatan pembelajaran memberikan dampak terhadap terbentuknya sikap self-confidence siswa. Hal ini bisa dijelaskan mengingat bahwa pembentuk utama dari kepercayaan diri adalah adanya interaksi antara siswa dengan guru yang sulit dipenuhi pada metode pembelajaran konvensional.

Penggunaan sarana IT pada kelompok RBL dengan Pendekatan Scientific menggunakan media e-learning juga akan memberikan dampak positip bagi meningkatnya kepercayaan diri siswa mengingat penguasaan terhadap teknologi merupakan tuntutan kehidupan pada era modern. Siswa yang sudah memiliki pemahaman dan kemampuan dalam mempergunakan media $e$-learning akan merasa unggul sehingga akan mampu bersikap lebih percaya diri. Hal ini sejalan dengan hasil penelitian Wahyudin (2016) yang menyatakan bahwa implementasi model e-learning mampu memberikan peningkatan sikap self-efficacy yang menjadi bagian dari aspek self-confidence siswa.

Dengan segala keunggulan yang dimiliknya, media e-learning dapat memberikan dukungan yang sangat bermanfaat bagi pengembangan metode RBL dengan Pendekatan Scientific yang sarat dengan kebutuhan informasi. Oleh karena itu, metode RBL dengan Pendekatan Scientific menggunakan media e-learning perlu terus dikembangkan agar dapat menjadi salah satu metode pembelajaran yang menarik, interaktif dan mudah difahami.

Pada aspek pengembangan self-confidence, guru memiliki tantangan untuk dapat mengkondisikan proses pembelajaran yang tidak hanya terfokus kepada transfer pengetahuan akademis (hard skills), melainkan juga mampu mengajarkan nilai-nilai sikap dan 
karakter (soft skill). Dengan demikian, siswa dapat menguasai hard skills maupun soft skills yang akan terintegrasi untuk membentuk individu yang tidak hanya unggul secara intelektual, namun juga memiliki kecerdasan emosional dan spiritual. Individu seperti inilah yang dapat diandalkan sebagai generasi penerus pembangunan di masa mendatang.

3. Korelasi Antara Kemampuan Berpikir Kreatif Matematis dengan Self-confidence

Berdasarkan hasil uji korelasi antara kemampuan berpikir kreatif matematis dengan self-confidence yang dilakukan terhadap hasil pretes, postes dan peningkatan dari nilai kemampuan berpikir kreatif matematis dan self-confidence, maka peneliti menemukan adanya korelasi antara kemampuan berpikir kreatif matematis dengan self-confidence siswa. Sesuai hasil analisa ditemukan adanya kecenderungan bahwa semakin baik tingkat kemampuan berpikir kreatif matematis, maka semakin tinggi pula self-confidence siswa.

Hal ini sesuai dengan kondisi dimana seorang pemikir yang kreatif dituntut untuk dapat bekerja dengan kemampuan yang tinggi, memiliki rasa percaya diri yang kuat dan merasa tertantang untuk menyelesaikan masalah meskipun tergolong baru dan belum dikuasai dengan baik.. Seseorang yang memiliki kemampuan berpikir kreatif akan memiliki keyakinan dan kepercayaan diri untuk menyelesaikan berbagai permasalahan dengan ide, gagasan dan kemampuannya. Sebaliknya, kepercayaan diri juga akan bisa meningkatkan kemampuan berpikir kreatif matematis seiring dengan tumbuhnya semangat, motivasi dan keyakinan bahwa semua permasalahan bisa diselesaikan dengan semangat dan kerja keras untuk terus belajar dalam meningkatkan kemampuan yang dimiliki.

Analisa data yang menyatakan adanya korelasi antara kemampuan berpikir kreatif matematis dengan self-confidence sejalan dengan hasil penelitian Rahman (2012) yang menyatakan bahwa self-concept siswa tentang matematika dalam pembelajaran berbantuan Geogebra mempengaruhi kemampuan berpikir kreatif matematis siswa. Dalam hal ini, semakin tinggi self-concept sebagai salah satu aspek yang terkait dengan self-confidence maka semakin tinggi pula tingkat kemampuan berpikir kreatif matematis siswa. Pada sisi lain, hasil penelitian Diana (2013) menyatakan bahwa tidak ada hubungan positip dan signifikansi antara selfconfidence dengan kemampuan berpikir kreatif matematis. Artinya, siswa yang memiliki selfconfidence rendah sangat mungkin memiliki kemampuan berpikir kreatif matematis yang tinggi, dan siswa yang memiliki self-confidence tinggi juga sangat mungkin ternyata memiliki kemampuan berpikir kreatif matematis yang rendah.

Penelitian tersebut menyatakan bahwa terdapat banyak faktor yang mempengaruhi tingkat kemampuan berpikir kreatif matematis, sehingga aspek self-confidence hanya memiliki sedikit kemungkinan untuk bisa mempengaruhi tingkat kemampuan berpikir kreatif matematis. Namun demikian, penelitian itu juga menyatakan bahwa tidak adanya korelasi antara self-confidence dengan kemampuan berpikir kreatif matematis bukan sesuatu yang bersifat mutlak. Tidak menutup kemungkinan bahwa seseorang yang memiliki self-confidence rendah, akan memiliki tingkat kemampuan berpikir kreatif matematis yang rendah atau sebaliknya.

Terkait dengan self-confidence, Foster (2016) menyatakan bahwa siswa yang memiliki kepercayaan diri memiliki keyakinan bahwa hasil yang baik hanya bisa diperoleh dengan usaha, tidak gentar menghadapi materi yang sulit, pandai memperoleh hasil yang baik dan bersikap tenang dalam menghadapi pelajaran seperti matematika. Sebaliknya siswa yang kurang memiliki kepercayaan diri cenderung merasa gugup dan menganggap dirinya lemah saat menghadapi pelajaran matematika.

Namun demikian, korelasi antara selfconfidence dengan kemampuan berpikir kreatif matematis dapat dipengaruhi oleh berbagai 
faktor seperti kemampuan siswa untuk berkonsentrasi, kondisi sosial ekonomi siswa, serta kemampuan guru dalam menyampaikan materi. Apabila berbagai faktor dimaksud berada dalam kondisi yang baik, maka kepercayaan diri dapat menjadi faktor pemicu bagi siswa untuk mengeluarkan potensi dan kemampuannya secara optimal.

Secara umum, hasil penelitian menunjukkan adanya respon positip dari siswa terhadap metode RBL dengan Pendekatan Scientific menggunakan media e-learning. Dalam hal ini, siswa beranggapan bahwa metode RBL dengan Pendekatan Scientific menggunakan media $e$ learning memberikan pengalaman belajar yang baru dimana siswa memiliki kesempatan untuk belajar dari banyak sumber, sekaligus memanfaatkan berbagai fitur teknologi informasi dengan segala kelebihan yang dimilikinya.

\section{KESIMPULAN}

Berdasarkan hasil penelitian yang telah dikemukakan pada bagian terdahulu, maka dapat diambil kesimpulan bahwa, terdapat perbedaan peningkatan kemampuan berpikir kreatif matematis dari siswa yang menerapkan model Resources-Based Learning dengan Pendekatan Scientific, siswa yang menerapkan model Resources-Based Learning dengan Pendekatan Scientific menggunakan media $e$ learning dan siswa yang mendapat pembelajaran konvensional. Siswa yang menerapkan model Resources-Based Learning dengan Pendekatan Scientific menggunakan media e-learning memperoleh peningkatan kemampuan berpikir kreatif matematis yang paling baik, diikuti siswa yang menerapkan model Resources-Based Learning dengan Pendekatan Scientific dan paling rendah siswa yang mendapat pembelajaran konvensional; siswa yang menerapkan model ResourcesBased Learning dengan Pendekatan Scientific menggunakan media e-learning memiliki selfconfidence yang paling baik, diikuti siswa yang menerapkan model Resources-Based Learning dengan Pendekatan Scientific dan paling rendah siswa yang mendapat pembelajaran konvensional; serta terdapat korelasi antara kemampuan berpikir kreatif matematis dengan self-confidence siswa dimana semakin tinggi tingkat kemampuan berpikir kreatif matematis, maka semakin baik pula self-confidence siswa. Namun demikian, kondisi korelasi bisa terganggu beberapa faktor antara lain ketidakmampuan untuk konsentrasi; kemampuan atau keadaan sosial ekonomi, serta kurangnya kemampuan guru dalam menyampaikan materi.

\section{REFERENSI}

Ahmatika, D. 2015. Peningkatan Kemampuan Berpikir Kreatif Matematis Dan Selfconfidence Siswa Smp Melalui Resources-Based Learning RBL Dengan Pendekatan Scientific : Penelitian Kuasi Eksperimen terhadap Siswa kelas VII salah satu SMPN Bandung. S2 Tesis, Universitas Pendidikan Indonesia : Tidak Diterbitkan.

Aliyah, U.H, et al. 2014. "Keefektifan Resource Based Learning Terhadap Kemampuan Pemecahan Masalah Peserta Didik Materi Lingkaran”. Jurnal Pendidikan Matematika dan Sains. Tahun II No. 1; 10-18.

Butler, M. 2012. "Resource Based Learning and Course Design”. Law Library Journal. Georgia State University College of Law, Legal Studies Research Paper No. 2011-24.

Kementerian Pendidikan dan Kebudayaan. 2016. Peraturan Menteri Pendidikan Dan Kebudayaan Nomor 20 Tahun 2016 tentang tentang Standar Kompetensi Lulusan Pendidikan Dasar dan Menengah. Jakarta. Kemendikbud.

Foster, C. 2016. Confidence and competence with mathematical procedures. 
Dahlia Fisher, R. Poppy Yaniawati

In in Supianti, Mira Mariani

Educational Studies in Mathematics, 91 2. pp. 271-288.

Jazuli, A. 2009. "Berfikir Kreatif Dalam Kemampuan Komunikasi Matematika". Prosiding Seminar Nasional Matematika dan Pendidikan Matematika Universitas Muhammadiyah Purwokerto. Pp. 209220.

Khususwanto. 2012. Pembelajaran Matematika dengan Pendekatan Resource- Based Learning untuk Meningkatkan Kemampuan Berpikir Kreatif Matematis dan Self-confidence Siswa SMP. Tesis: UPI; Bandung : Tidak Diterbitkan.

Diana, J.K. 2013. Hubungan Antara Kepercayaan Diri dan Kemampuan Berpikir Kreatif Matematis dengan Hasil Belajar Matematika Siswa Kelas XI Akuntansi SMK Penabur Purworejo. Skripsi Universitas Satya Wacana Salatiga : tidak diterbitkan.

McPheat, S. 2010. Personal Confidence \& Motivation. United Kingdom. MDT Training \& Ventus Publishing ApS.

Nurqolbiah, S. 2016. "Peningkatan Kemampuan Pemecahan Masalah, Berpikir Kreatif dan Self-confidence Siswa Melalui Model Pembelajaran Berbasis Masalah”. Jurnal Penelitian Pendidikan dan Pengajaran Matematika. Vol. 1 No. 3 hal. 225-240.

Rahman, R. 2012. "Hubungan Antara SelfConcep Terhadap Matematika dengan Kemampuan Berpikir Kreatif Matematik Siswa”. Jurnal ilmiah Program Studi Matematika STKIP Siliwangi Bandung. Vol 1. No. 1. Februari 2012.

Ruggiero, R.V. 2013. The Art of Thinking. A Guide to Critical and Creative Thought Tenth Edition. New York: Longman, An
Imprint of Addison Wesley Longman, Inc.

Wahyudin, Y. 2016. Analisis Kemampuan Penalaran Matematis dan Self-Efficacy Siswa SMA Melalui Implementasi Model Pembelajaran E-learning. Tesis, Unpas; Bandung : Tidak Diterbitkan.

Yaniawati, R.P. 2012. "Pengaruh e-learning untuk meningkatkan Daya Matemati Mahasiswa". Cakrawala Pendidikan. Nopember 2012, Th. XXXI, No. 3; 381393.

Yaniawati, R.P. 2013. "E-learning to Improve Higher Order Thinking Skills HOTS of Students." Journal of Education and Learning. 72; pp. 109-120.

Yaniawati, R.P. 2016. "Using Mathematics Assessment Based On E-learning To Improve Students' Mathematical Power". International Journal of Management and Applied Science. II 10, Pp. 130-135. 